\title{
Adapting a Foreign Direct Investment Strategy to the Knowledge Economy: The Case of Singapore's Emerging Biotechnology Cluster
}

\author{
DAVID FINEGOLD ${ }^{1}$, POH-KAM WONG ${ }^{2}$ and TSUI-CHERN CHEAH ${ }^{3}$
}

[Paper first received, September 2003; in final form, June 04]

\begin{abstract}
The Singapore Government has identified biotechnology as one of the four pillars of the economy for the twenty-first century. For the last forty years, Singapore has pursued a very successful economic growth strategy of attracting investment from leading multinationals through a combination of financial incentives, world-class infrastructure, a highly literate workforce and a business-friendly regulatory environment. In the biotechnology industry worldwide, however, the typical development pattern has been very different: new start-up companies backed by venture capitalists clustered around leading research universities. This article examines the development of the biotechnology cluster in Singapore, showing how a modified version of Singapore's traditional growth model is co-existing with a more typical biotechnology development pattern.
\end{abstract}

\section{Introduction}

Like many Asian countries, Singapore has set its sight on developing a world-class biotechnology industry (Shahi, 2004). The Government's biotechnology initiatives began in the 1980s, but it is only in the last three to four years that it has signalled its intention to make the biomedical industry the fourth pillar of the economy with a major investment of resources (Arnold, 2003). Biotechnology was given strong impetus as the government realized the risk of over-dependence on information technology (IT) and sought to take advantage of growing opportunities created by recent advances in the biosciences.

This article examines the Singapore Government's efforts to develop the city-state into a major biotechnology cluster. Singapore's experience is instructive insofar as it throws light on a key theoretical and policy issue: to what extent can the development strategy of attracting and leveraging foreign direct investment (FDI) from global multinationals (MNCs), which has worked so well for Singapore in industries like petrochemicals, electronics and ICT (Wong, 2001, 2002), offer an alternative to the reliance on science-driven, dedicated biotechnology

1. Keck Graduate Institute, Strategy \& Organization Studies, 535 Watson Dr., Claremont, CA 91711, (909) 607-9651, david_finegold@kgi.edu

2. Entrepreneurship Centre, National University of Singapore, Singapore 118412, bizwpk@nus.edu.sg

3. Keck Graduate Institute, Strategy \& Organization Studies, 535 Watson Dr., Claremont, CA 91711, (909) 607-9651,tcheah@kgi.edu 
firms $(\mathrm{DBF})$ that has been the common pattern in other countries? Or is the business ecosystem that is needed for the biotechnology industry to thrive so distinctive that a different public policy approach is needed? To assess the potential viability of Singapore's biotechnology cluster we use a framework for analyzing the conditions necessary to create self-sustaining, high-skill ecosystems (HSE) (Finegold, 1999). This draws on related research on industrial districts (Piore \& Sabel, 1984), clusters (Porter, 1998), collective learning (Teubal, 1997) and the distinctive requirements of the biotechnology industry (Cooke, 2003). The HSE model consists of four distinct elements - catalysts, resources, supportive environment, and connectivity - that are common to the development of thriving natural ecosystems and biotechnology clusters.

\section{Singapore's Efforts to Build a Biotechnology HSE}

\subsection{Catalysts}

As with naturally occurring ecosystems, there is a strong element of historical contingency in how and where high-technology regions are formed (Arthur, 1989). To trigger the development of successful high-tech enterprises, these regions require some catalysts, such as innovations produced by basic research or demand from sophisticated customers. The strong positive externalities and high level of risk associated with basic research or the development of new technologies suggest that there is a major role for the government to play in funding these catalytic activities and acting as a lead user (Arrow 1962; Cohen \& Fields, 1999). The large biotechnology cluster surrounding Washington, DC, for example, is a direct outgrowth of the major Federal Government investment in life science research and the wealth of manpower it drew to the DC area (Feldman \& Francis, 2003).

As with most aspects of its economy, Singapore's move into the biomedical sciences was strongly driven by the government. The Singapore government has articulated a vision of turning Singapore into Asia's premier hub for biomedical sciences, with world-class capabilities across the entire value chain, from basic research to clinical trials, product/process development, full-scale manufacturing and healthcare delivery (Biomed-Singapore, 2003). Through intensive study of other countries' approaches, it recognized early on that building a successful biomedical industry would be a very long-term project and that its traditional model of industrial development would need to be modified to fit the distinctive requirements of the biomedical sector.

The two arms of the government with responsibility for establishing the country as a biomedical science hub are the Agency for Science, Technology and Research (A*STAR), formerly known as the National Science and Technology Board, and the Economic Development Board (EDB). A*STAR has put in place policies, resources, and a research and education architecture intended to build biomedical science competencies internally under the auspices of the Biomedical Research Council. Singapore's first foray into the biomedical sciences sector was through the establishment of the Institute of Molecular and Cellular Biology (IMCB) in 1987 at the National University of Singapore. Other research institutes were subsequently set up between 1996 and 2002, including the Bioinformatics Center, the Genome Institute of Singapore, the Bioprocessing Technology Centre, and the Institute of Bioengineering and Nanotechnology. A*STAR has already invested over $\$ 500$ million in these new research centres, with another $\mathrm{S} \$ 1$ billion in funding committed through 2006. Basic research is supported by four types of grants: project grants provide seed-funding for new investigators; programme grants support more extensive research programmes of established investigators; co-operative grants sponsor inter-disciplinary work; lastly, core competence grants are meant for research centres to develop or strengthen capabilities in areas of 
strategic importance. A*STAR is chaired by Phillip Yeo, who as chairman of EDB has overseen the implementation of Singapore's economic development strategy for the last 15 years. As the new chairman of A*STAR, he has been charged with the transformation of Singapore into a biomedical hub within five years.

The arm of government responsible for bringing in investments and generating long-term economic value for the country is EDB. In the early 1980s, EDB established a venture capital office in the US to invest in DBFs, to establish networks, and to create global visibility for Singapore among US venture capitalists. ${ }^{1}$ The primary objective at that stage was to use venture funding, and the access it provided, to some of the leading first-generation DBFs so as to learn about the biomedical science industry, rather than to attract companies to Singapore. It was only from the late-1990s that EDB began selectively to invest in DBFs that were willing to bring key new technologies and generate higher value-added research jobs in Singapore. For example, to create one of the most ambitious Singapore biotechnology start-ups, S*Bio, EDB formed a strategic alliance with Chiron by offering a multi-million dollar deal to transfer the US DBF's technology platform to a new drug discovery start-up in Singapore, in which Chiron was then given a significant ownership stake.

\subsection{Nourishment}

Once catalysed, ecosystems require a sustained flow of nutrients - human and financial capital - to fuel their growth. The biomedical science industry is very capital intensive and risky, with most new ventures failing to generate a return on their investment. With no history of home-grown, high-tech companies, Singapore has not developed a community of venture capitalists or other private investors who are knowledgeable about and interested in investing in biomedical start-ups. Those investors interested in this sector have tended to put their resources into US firms with more proven track records and lower perceived risk. To fill this investment gap, the Singapore government, through EDB, has committed an additional $\mathrm{S} \$ 2$ billion to the bioscience area. Half the amount is invested in three bioscience funds: Life Sciences Investments, PharmBio Growth Fund, and Singapore BioInnovations, which make investments in local start-ups and Singapore-based joint ventures, and provide financial incentives to attract MNCs to Singapore. Another $\mathrm{S} \$ 1$ billion is set aside to attract three to five world-class corporate centres of research (EDB, 1999; Saywell, 2001).

Aside from funding, another area essential to fuelling the life-science industry is manpower development. Recognizing that developing world-class scientists and having them generate new research breakthroughs takes decades, the Singapore government has developed short-, medium- and long-term approaches to building the necessary skills. In the short-term, A*STAR has offered generous financial incentives to attract internationally renowned scientists to set up research labs in Singapore. These include a Nobel Prize winner, Dr. Sidney Brenner, a former director of the US National Cancer Institute, Dr. Edison Liu, and a premier cancer researcher from Japan, Professor Yoshiaki Ito. These foreign biomedical stars are seen as a way to provide immediate credibility to Singapore's nascent research efforts and also to serve as a magnet to attract top young scientists to work and train in Singapore. In addition to these star scientists, the government is helping firms recruit experienced scientific and managerial leaders from foreign bioscience firms to develop some of Singapore's new start-up companies, since there is a lack of local talent with the relevant experience. The medium-term strategy involves sending the top students from Singapore to the leading foreign research universities for graduate science and technology education. The government pays for their education provided that they return to Singapore when they complete their studies. In the long-term, the government hopes that Singapore's own universities and research institutes, 


\section{David Finegold, Poh-Kam Wong and Tsui-Chern Cheah}

bolstered by alliances with top universities such as Johns Hopkins, MIT, Duke University, Columbia and the Indian Institute of Technology that have all established a presence in Singapore, can develop their own bioscience manpower to generate the intellectual property for future local start-ups.

\subsection{Supportive Environment}

As in biological ecosystems, there is a need for a supportive rather than a hostile environment, if the population and individual species are to grow. A region or a nation's regulatory and cultural regime may either attract and develop or discourage bioentrepreneurs or existing firms from taking the risks needed to turn scientific innovations into successful businesses. Three characteristics of an environment that support a biomedical HSE are a specialized infrastructure, a climate attractive to knowledge workers, and regulatory policies that protect IP and support risk-taking. In addition to excellent general infrastructure (efficient transportation, high speed internet network, a safe and clean city), Singapore has gone one step further by building the Tuas Biomedical Park for bioscience manufacturing and the Biopolis, an ambitious city within a city that specifically caters to the unique research needs of the biomedical sciences, such as a large vivarium to house the mice essential for pre-clinical studies. Opening its first phase in June 2003, the Biopolis is a $\$ \$ 300$ million project with 190 hectares of buildings located near the National University of Singapore. Besides having $\mathrm{A}^{*} \mathrm{STAR}$ 's five biomedical research institutes as the anchor tenants, Biopolis is intended to attract biomedical MNCs, start-ups, and support services such as lawyers and patent agents to locate there. The government hopes that creating such a cluster, which will include plenty of restaurants, social spaces and some living-quarters, will create informal networks for knowledge sharing and accelerate the growth of a critical mass of biomedical expertise in Singapore.

Singapore also has put in place a regulatory environment that is broadly supportive of biotechnology. The Bioethics Advisory Committee was formed in 2001, at the time of the US stem cell controversy, to develop recommendations on the legal, ethical and social issues of human-biology research. The government accepted the Committee's recommendation that human cloning not be permitted, but doing stem cell research or the use of cloning as a therapeutic tool is to be allowed (Kong, 2003). This early and clear legal support for stem-cell research, plus government financial support, has helped Singapore create several stem cell companies, including ES Cell International that hired Alan Colman from Scotland, where he was one of the lead scientists in the cloning of Dolly the sheep. Singapore stem-cell researchers have followed strict international guidelines, which require seeking consent from couples and using only excess embryos from IVF treatment (Chang, 2001). Because of this, the US National Institute of Health has allowed the US federal government to fund research that uses Singapore-produced stem cells.

Singapore also offers strong IP protection, a prerequisite for establishing research-based biotechnology firms, and one of the weaknesses of some of its leading potential Asian competitors (especially China and India). But while the general legal framework for IP clearly supports biotechnology development, the way in which IP will be administered within state-funded institutions may not be as favourable. In 2002, A*STAR launched Exploit Technologies, a new vehicle to commercialize IP generated by the national research institutes. It functions as a centralized technology transfer office for IP management, licensing, and commercialization. Centralization of IP ownership runs directly counter to the path the US took with the landmark Bayh-Dole Act in 1982 which gave universities the freedom to commercialize federally funded research and is widely credited with helping kick-start the biotechnology revolution. Retaining central control of IP risks stifling creativity, but is more 
in keeping with the Singapore Government's traditionally direct involvement in economic development (Vig, 2003).

The absence of risk-taking in Singapore impedes the development of an entrepreneurial culture. It is not possible to make progress in biotechnology and to create new firms without many failures and mistakes, and without a free exchange of ideas among those with different viewpoints, characteristics that are not yet well incorporated into Singapore's culture, as shown in this example from a job interview a manager at Lilly Systems Biology had with a Singapore scientist:

One standard question we use in US interviews is, "Give me an example where you made a mistake and what you learned from it." A common response [in Singapore] is, "I don't make mistakes." Once, when probing further, I was told, "Yes, I made one mistake: I had a different opinion from my boss and told him." When asked what was the mistake in that, [the interviewee] said, "I learned not to have another opinion." This is a true story and he was a $\mathrm{PhD}$.

\subsection{Connectivity}

To be successful, innovations need more than an initial spark, abundant resources and a supportive environment. Especially R\&D-intensive, high technology-orientated firms need rich, multi-layered, and cross-border networks to be successful (Cooke, 2003; Wolter, 2002). As in the IP area, the government appears to exercise strong, centralized control over most aspects of Singapore's biomedical industry development. Characteristic of the top-down, government-led strategy for industrial development that it has successfully used in the past, the Singapore Government has orchestrated the entire biomedical development effort, starting with the establishment of a Life-Science Ministerial Committee (chaired by a deputy prime minister) to oversee long-term strategy formulation, followed by instituting a highly coordinated implementation approach involving EDB, A*STAR, and the Ministries of Education, Manpower, and Health. While this top-down, coordinated approach has worked well in the past to accelerate the development of competencies in new industrial clusters (e.g. the hard-disk-drive industry, see Wong [2001]) and may be particularly advantageous in terms of long-term resource development for an industry like biotechnology (e.g. manpower development), it runs the risk of stifling alternative approaches and marginalizing non-conforming groups. In particular, a company that is outside of this community may find it difficult to secure resources, such as funding. This may have hampered the development of independent biomedical start-ups because very little funding exists that is not of government origin (Ginzel, 2003).

Another area of weakness is that informal cooperation between firms and research institutes has been relatively limited so far. For example, one firm we interviewed mentioned approaching a research institute in the same building regarding the possibility of collaboration, beginning with a request to use an expensive piece of equipment in the lab that had excess capacity. It was unable to interest the lab in partnering, however. Several factors may explain this. First, other than IMCB, the institutes are very new, and focused on getting their research programmes up and running. In addition, the academic culture of research institutes focuses on basic research and publishing, and the researchers are relatively well-funded by the government; thus the advantages of collaboration with firms, such as securing additional research funding or the opportunity to spin out a company, are not a high priority for the research staff. Finally, as noted above, the culture among research scientists and managers in Singapore appears to be risk-averse; consequently, collaboration and sharing of information 
may be perceived as risky and inter- and intra-organizational collaborations are not the norm (Stein, 2003).

\section{Progress to Date}

While Singapore appears to have put in place some of the elements needed for a biotechnology HSE, it remains too early to judge whether an ecosystem will flourish. This section provides some preliminary assessment of the development progress of the fledgling biomedical industry in Singapore, based on a combination of interviews, firm case-studies, analysis of archival data, and a review from secondary sources (e.g. IDC, 2002; Triendl \& Yoon, 2001). Interviews were conducted in Singapore with representatives from EDB, A*STAR, the National University of Singapore, two biotechnology incubators, six biomedical firms, and several consultants and VCs. The Annual Singapore Biomedical Sciences Directory was used as the initial source for information on companies based in the pharmaceutical, biotechnology, medical technology, or healthcare services industries, as well as on research/academic institutions, government bodies, venture capitalists, and various supporting industries.

The biomedical industry in Singapore today is dominated by large, foreign-owned pharmaceutical companies (see Table 1), with DBFs still in an embryonic stage of development. Firms like GlaxoSmithKline (GSK), Schering-Plough, and Merck first came to Singapore to take advantage of the country's well-established competency in manufacturing. The majority of these firms are headquartered in the United States, and they manufacture pharmaceutical bulk active or intermediate products. Companies such as Genencor, AstraZeneca, and Bristol Myers Squibb (BMS) also established regional headquarters in Singapore because it is a major Asian business hub.

As can be seen in Table 2, Singapore's pharmaceutical manufacturing output (SSIC 242) was relatively low until the mid-1990s, but has grown very rapidly at an average compound growth rate of close to $30 \%$ from $\$ \$ 1.4$ billion in 1995 to $\$ \$ 8.2$ billion in 2002 , primarily for export. Production was concentrated in a few large firms. As of 2002, there were only 38 companies classified in the pharmaceuticals sector, producing some $\$ \$ 215$ million of output per establishment. This was significantly higher than the average of $\$ 35.7$ million of output per establishment for all manufacturing sectors.

The government's efforts to encourage MNCs to locate more knowledge-intensive work in Singapore appear to be paying off as value-added within the sector has grown rapidly, increasing from $\$ 1.1$ billion in 1995 to $\$ 4.9$ billion in 2002. However, for policymakers who see biotechnology as a potential solution to the problem of increasingly skilled jobs moving to lower-wage nations (Flanigan, 2004), it is important to note that the industry has generated limited employment growth in Singapore as elsewhere. In 2002, only 3,200 people worked in the pharmaceutical sector, less than $1 \%$ of the total manufacturing employment in Singapore. Reflecting the very high capital intensity of the pharmaceutical industry, the average value added per worker in 2002 was over $\mathbf{S} \$ 1.5$ million (having increased substantially from less than $\$ \$ 600,000$ in 1995), 15 times the average for all Singapore manufacturing.

Table 3 shows the R\&D expenditure in the biomedical sector rising from $\mathrm{S} \$ 43.1$ million in 1993 to $\$ \$ 310.7$ million in 2001 , an average compound growth rate of $28 \%$ per annum. While the growth is rapid, the total level of investment is still dwarfed by the R\&D budgets of individual pharmaceutical firms or single large research universities in the US. The number of RSEs (research scientists and engineers) in the sector also grew quite rapidly from 447 in 1993 to 2055 in 2001 (see Table 4). As a share of total R\&D expenditure, however, the biomedical industry still remains small, accounting for only $9.6 \%$ in 2001 , up from $4.3 \%$ in 1993. Reflecting the success of EDB in attracting global pharmaceutical companies to initiate 
Table 1. Major Foreign Pharmaceutical Companies operating in Singapore

\begin{tabular}{|c|c|c|c|}
\hline Company & Business Focus & $\begin{array}{l}\text { Date of } \\
\text { Establishment }^{2}\end{array}$ & Size of Operation ${ }^{3}$ \\
\hline $\begin{array}{l}\text { GlaxoSmith } \\
\text { Kline (GSK) }\end{array}$ & $\begin{array}{l}\text { Bulk active } \\
\text { biomanufacturing } \\
\text { \& regional } \\
\text { headquarter }\end{array}$ & 1989 & $\begin{array}{l}>\mathrm{S} \$ 1 \text { billion invested. } \\
\text { In } 2000 \text { share } 17 \% \text { of total GSK } \\
\text { vaccine studies and manufactures } \\
>10 \text { products for global market }\end{array}$ \\
\hline Schering-Plough & $\begin{array}{l}\text { Bulk active } \\
\text { biomanufacturing } \\
\text { (Clarityne) }\end{array}$ & $\begin{array}{l}1994 \\
1997-\text { began } \\
\text { production }\end{array}$ & $\begin{array}{l}3 \text { of } 6 \text { manufacturing plants built in } \\
\text { Singapore with a total investment of } \\
\text { US } \$ 730 \text { million in Singapore, } 29,000 \\
\text { employees worldwide }\end{array}$ \\
\hline $\begin{array}{l}\text { Genset } \\
\text { Singapore }\end{array}$ & $\begin{array}{l}\text { Oligonucleotide } \\
\text { manufacturing }\end{array}$ & 1997 & $\begin{array}{l}536 \text { employees worldwide (2000) with } \\
\text { manufacturing sites in US, Japan, } \\
\text { Singapore }\end{array}$ \\
\hline Wyeth-Ayerst & $\begin{array}{l}\text { Biomanufacturing } \\
\text { (Infant nutritional, } \\
\text { Premelle) }\end{array}$ & $\begin{array}{l}1999 \\
2002 \text {-began } \\
\text { operation }\end{array}$ & $\begin{array}{l}\text { Will employ up to } 600 \text { employees at } \\
\text { full capacity }{ }^{5}\end{array}$ \\
\hline Aventis & $\begin{array}{l}\text { Bulk active } \\
\text { biomanufacturing } \\
\text { (Enoxaparin) }\end{array}$ & 2000 & 65,000 employees worldwide \\
\hline Pfizer & $\begin{array}{l}\text { Active ingredient } \\
\text { biomanufacturing }\end{array}$ & $\begin{array}{l}2000 \\
\text { (fully operational } \\
\text { in 2004) }\end{array}$ & $\begin{array}{l}241 \text { employees in Singapore as } \\
\text { of mid 2003, 98,000 worldwide. }\end{array}$ \\
\hline $\begin{array}{l}\text { Merck Sharp } \\
\& \quad \text { Dohme }\end{array}$ & $\begin{array}{l}\text { Bulk active } \\
\text { biomanufacturing } \\
\text { (Vioxx, Singulair) }\end{array}$ & $\begin{array}{l}1993^{6} \text { (operational } \\
\text { in 2001) }\end{array}$ & $\begin{array}{l}>200 \text { employees in Singapore } \\
62,000 \text { employees worldwide }\end{array}$ \\
\hline Novo Nordisk & $\begin{array}{l}\text { Administration, } \\
\text { clinical trial } \\
\text { coordination }\end{array}$ & $\begin{array}{l}1989 \text { - regional } \\
\text { HQ } \\
1999 \text { - clinical trial } \\
\text { center }\end{array}$ & $\begin{array}{l}50 \text { employees in Singapore, } \\
18,221 \text { employees worldwide }\end{array}$ \\
\hline Quintiles & $\begin{array}{l}\text { Clinical research } \\
\text { organization }\end{array}$ & 1995 & $\begin{array}{l}60 \text { employees in Singapore, } 800 \\
\text { employees in Asia-Pacific, } 18,000 \\
\text { employees worldwide Investment of } \$ 10 \\
\text { million for clinical trial supplies facility }\end{array}$ \\
\hline Covance & $\begin{array}{l}\text { Clinical research } \\
\text { organization }\end{array}$ & $\begin{array}{l}\text { 1996-Clinical } \\
\text { development } \\
\text { 2000-Lab site }\end{array}$ & $\begin{array}{l}118 \text { employees in Singapore, } 7,900 \\
\text { employees worldwide } \\
\text { Investment of }>\text { US } \$ 1 \text { million }\end{array}$ \\
\hline $\begin{array}{l}\text { Pharmacia \& } \\
\text { Upjohn }\end{array}$ & $\begin{array}{l}\text { Clinical research \& } \\
\text { medical services }\end{array}$ & 2000 & See note $^{8}$ \\
\hline $\begin{array}{l}\text { Genelabs } \\
\text { Diagnostic }\end{array}$ & $\begin{array}{l}\text { Diagnostic } \\
\text { biotechnology }\end{array}$ & 1985 & $\begin{array}{l}42 \text { employees in Singapore in } \\
2001,70-90 \text { employees }\end{array}$ \\
\hline PerkinElmer & Thermal cycler & 1998 & $\begin{array}{l}\text { Opened } \mathrm{S} \$ 10 \text { million manufacturing } \\
\text { and } \mathrm{R} \& \mathrm{D} \text { facility }\end{array}$ \\
\hline $\begin{array}{l}\text { Sangui } \\
\text { Singapore }\end{array}$ & $\begin{array}{l}\text { Blood supplements } \\
\text { and therapeutics }\end{array}$ & 1999 & $\begin{array}{l}\text { 5-15 employees in Singapore, } 30 \\
\text { employees worldwide (mid 2002) }\end{array}$ \\
\hline $\begin{array}{l}\text { Becton } \\
\text { Dickinson }\end{array}$ & $\begin{array}{l}\text { Instrumentation, } \\
\text { medical products }\end{array}$ & $\begin{array}{l}\text { 1986-Medical } \\
\text { product }\end{array}$ & $\begin{array}{l}1000 \text { employees in Singapore, } 2,500 \\
\text { employees in Asia }\end{array}$ \\
\hline $\begin{array}{l}\text { Cell } \\
\text { Transplants } \\
\text { International }\end{array}$ & $\begin{array}{l}\text { Cardiac myoblast } \\
\text { therapeutics }\end{array}$ & 2000 & 15 employees in Singapore \\
\hline
\end{tabular}


Table 1. Major Foreign Pharmaceutical Companies operating in Singapore-continued

\begin{tabular}{|c|c|c|c|}
\hline Company & Business Focus & $\begin{array}{l}\text { Date of } \\
\text { Establishment }^{2}\end{array}$ & Size of Operation ${ }^{3}$ \\
\hline $\begin{array}{l}\text { Lilly Systems } \\
\text { Biology }\end{array}$ & $\begin{array}{l}\text { Systems biology } \\
\text { R\&D }\end{array}$ & 2001 & $\begin{array}{l}29 \text { employees in Singapore, } \\
41,000 \text { worldwide }\end{array}$ \\
\hline Novartis & $\begin{array}{l}\text { Institute for } \\
\text { Tropical Diseases }\end{array}$ & 2002 & $\begin{array}{l}\text { Will house } 70 \text { scientists in Singapore, } \\
77,200 \text { employees }\end{array}$ \\
\hline Surromed & $\begin{array}{l}\text { Biomarker } \\
\text { discovery tools }\end{array}$ & 2001 & $\begin{array}{l}25 \text { employees in Singapore, then } \\
\text { disbanded }^{9}\end{array}$ \\
\hline Affymetrix & Microarrays & 2001 & $\begin{array}{l}\text { R\&D centre is US } \$ 25 \text { million } \\
\text { investment, } 877 \text { employees worldwide } \\
\text { (2002) }\end{array}$ \\
\hline ViaCell & $\begin{array}{l}\text { Stem cell } \\
\text { therapeutics }\end{array}$ & 2002 & $\begin{array}{l}\text { US } \$ 4 \text { million invested over a } 5 \text {-yr } \\
\text { period. } 138 \text { employees worldwide } \\
(2001)\end{array}$ \\
\hline $\begin{array}{l}\text { PharmaLogicals } \\
\text { Research }\end{array}$ & $\begin{array}{l}\text { Cancers and other } \\
\text { diseases in Asians }\end{array}$ & 2002 & $\begin{array}{l}\mathrm{S} \$ 142 \text { million over the next three } \\
\text { years into research on drugs }\end{array}$ \\
\hline Schering-Plough & $\begin{array}{l}\text { Pilot plant, } \\
\text { development } \\
\text { laboratories, } \\
\text { supplying }\end{array}$ & 2000 & $\begin{array}{l}\text { Constructing US } \$ 25 \text { million } \\
\text { Chemical R\&D centre }\end{array}$ \\
\hline Oculex Asia & $\begin{array}{l}\text { Opthalmic drug } \\
\text { delivery systems }\end{array}$ & 1995 & $\begin{array}{l}13 \text { employees in Singapore, } \\
59 \text { employees worldwide (mid 2000) }\end{array}$ \\
\hline
\end{tabular}

R\&D activities in Singapore, the private sector's share of total biomedical R\&D spending has increased from $8.4 \%$ in 1993 to $28.5 \%$ in 2001 (Table 4).

While there are no reliable statistical estimates of the size of Singapore's DBF sector, it thus far accounts for only a small fraction of the output of the traditional pharmaceutical industry. Only a handful of DBFs have been founded in Singapore with the majority established in 2000 or later (see Table 6). The main focus areas for Singapore's DBFs are: drug discovery and development, medical devices, stem cells, and bioinformatics, with stem cells appearing to be the most globally competitive. Only two drug-discovery companies have products, Lynk Biotechnology and AP Genomics. Some have drug candidates in their pipeline while others are still in the extremely early stages of research. All the bioinformatics firms have some products in the market because product development in software is significantly shorter than it is for drugs. Given Singapore's traditional strength in electronics and miniaturization, it is surprising that there are not more medical device firms. For example, the country has a world-class eye institute that has spun off some technologies. In most cases however, there are no great incentives for doctors to create firms as they continue to enjoy good access to new technologies as practicing physicians (Stein, 2003). The absence of a domestic agricultural industry and arable land has meant that Singapore has not spawned any bio-agricultural firms.

In contrast to the fledgling development of DBFs, EDB has been seeking to move Singapore into the higher value-added portions of the biomedical industry value chain by encouraging foreign companies to set up R\&D or clinical research operations in Singapore. Some prominent early examples of these partnerships with MNCs include $\mathrm{S} * \mathrm{Bio}$, Merlion, and Lilly Systems Biology. S*Bio, as noted, was established as a joint venture between Chiron and the EDB using Chiron's technology platform to develop products for cancer and 


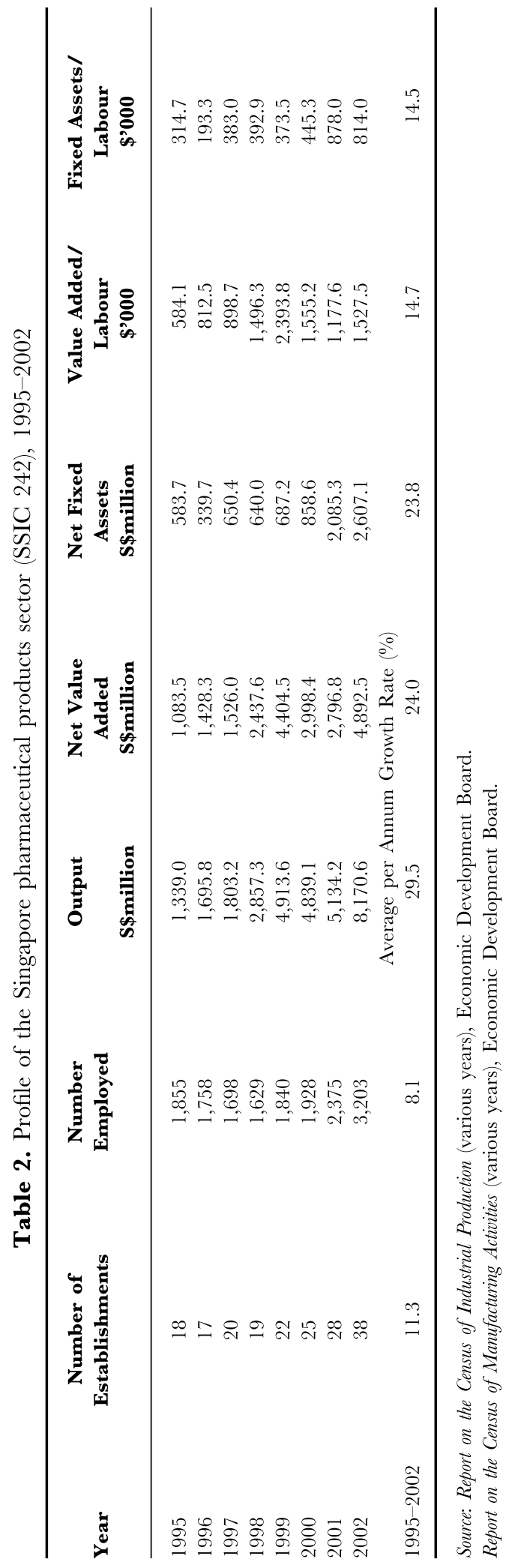


Table 3. $R \& D$ expenditure by firms in the life sciences industry, 1993-2001

\begin{tabular}{lcc}
\hline Year & No. of firms & $\begin{array}{c}\text { R\&D expenditure } \\
(\mathbf{S \$ m})\end{array}$ \\
\hline 1993 & & 24.8 \\
1994 & & 38.6 \\
1995 & & 34.4 \\
1996 & 45 & 37.86 \\
1997 & 50 & 58.34 \\
1998 & 57 & 63.81 \\
1999 & 54 & 89.68 \\
2000 & 43 & 83.48 \\
2001 & 48 & 113.58 \\
\hline
\end{tabular}

Source: National Survey of RED in Singapore (various years), Agency for Science, Technology and Research.

Table 4. Research Scientists and Engineers (RSEs) in the biomedical sector; ( $\$$ \$ million), 1993-2001

\begin{tabular}{lcccc}
\hline \multicolumn{4}{c}{ No. of RSEs } & \\
\cline { 2 - 4 } Year & PhD (a) & Master $(\mathbf{b})$ & Total $(\mathbf{c})$ & $\begin{array}{c}(\mathbf{a}+\mathbf{b}) /(\mathbf{c}) \\
(\mathbf{p e r c e n t a g e})\end{array}$ \\
\hline 1993 & 139 & 176 & 447 & 70.5 \\
1994 & 116 & 157 & 386 & 70.7 \\
1995 & 131 & 260 & 570 & 68.6 \\
1996 & 158 & 193 & 507 & 69.2 \\
1997 & 203 & 177 & 556 & 68.3 \\
1998 & 202 & 203 & 625 & 64.8 \\
1999 & 238 & 164 & 654 & 61.5 \\
2000 & 300 & 243 & 1333 & 40.7 \\
2001 & 610 & 453 & 2055 & 51.7 \\
\hline
\end{tabular}

Includes biomedical sciences and biomedical engineering

Source: National Survey of RED in Singapore (various years), Agency for Science, Technology and Research.

infectious diseases, especially those in Asia. Merlion originated as a joint venture between Glaxo and the EDB to perform more traditional drug-discovery by screening natural samples from across Asia for possible drug targets. After the merger that formed GSK, this unit was spun off and was privatized as a stand-alone business, with Merlion obtaining all of GSK's vast library of natural compounds along with its Asian samples. Today, Merlion owns one of the world's best private collections of natural samples with close to half a million extracts that they are screening for potential drugs, and has grown through collaborations with international drug companies, including Merck, British Biotech and NovImmume.

Lilly Systems Biology (LSB) is a wholly owned subsidiary of Lilly that was launched in Singapore in 2002 with generous, multi-year financial incentives from EDB. LSB's mission is to integrate various biological data and approach the problem of studying complex diseases from a more encompassing perspective of a cell and its system. Through intensive use of computational biology, LSB hopes to discover new drug-targets and biomarkers, and better understand mechanisms of action within the cell.

In addition to drug-discovery firms, Singapore has recently begun to market itself as a 
Table 5. R\&D expenditure in the biomedical sector. ( $\$ \$$ million), 1993-2001

\begin{tabular}{lccccc}
\hline Year & $\begin{array}{c}\text { Private } \\
\text { sector }\end{array}$ & $\begin{array}{c}\text { Higher education } \\
\text { sector }\end{array}$ & $\begin{array}{c}\text { Government } \\
\text { sector }\end{array}$ & PRIC sector & Total \\
\hline 1993 & 3.64 & 32.10 & 7.38 & 0.00 & 43.11 \\
1994 & 5.04 & 39.54 & 14.83 & 0.00 & 59.41 \\
1995 & 29.10 & 37.04 & 15.32 & 0.00 & 81.78 \\
1996 & 7.75 & 42.43 & 18.18 & 0.10 & 68.45 \\
1997 & 15.01 & 47.52 & 25.17 & 3.48 & 91.19 \\
1998 & 24.78 & 52.05 & 35.61 & 5.85 & 118.29 \\
1999 & 37.10 & 53.12 & 29.05 & 3.62 & 122.89 \\
2000 & 46.95 & 62.46 & 32.53 & 15.62 & 157.57 \\
2001 & 88.43 & 87.32 & 57.90 & 77.06 & 310.70 \\
\hline
\end{tabular}

Includes biomedical sciences and biomedical engineering

Source: National Survey of RED in Singapore (various years), Agency for Science, Technology and Research.

Table 6. Dedicated Biotechnology Firms founded in Singapore*

\begin{tabular}{|c|c|c|c|}
\hline Company & Business Focus & Products/services & $\begin{array}{l}\text { Date of } \\
\text { Establishment }\end{array}$ \\
\hline S*Bio & Drug discovery & $\mathrm{N} / \mathrm{A}$ & 2000 \\
\hline Lynk Biotechnology & $\begin{array}{l}\text { Drug discovery and } \\
\text { development }\end{array}$ & $\begin{array}{l}\text { Biolyn }{ }^{\mathrm{TM}} \text { Hair Serum Several } \\
\text { leads }\end{array}$ & 2000 \\
\hline APGenomics & $\begin{array}{l}\text { Genomics-based } \\
\text { products, services, } \\
\text { and technology }\end{array}$ & $\begin{array}{l}\text { Dengue SmartPGR } \\
\text { diagnostic } \\
\text { kit }\end{array}$ & 2000 \\
\hline Qugen & Gene therapy & 3 products nearing clinical & 2001 \\
\hline Agenica & $\begin{array}{l}\text { Breast cancer } \\
\text { treatment }\end{array}$ & $\mathrm{N} / \mathrm{A}$ & 2001 \\
\hline $\begin{array}{l}\text { Merlion } \\
\text { Pharmaceuticals }\end{array}$ & Drug discovery & $\mathrm{N} / \mathrm{A}$ & 2002 \\
\hline Biosensors & $\begin{array}{l}\text { Minimally invasive } \\
\text { surgical devices }\end{array}$ & Gatheters, transducers, stents & 1990 \\
\hline $\begin{array}{l}\text { ES Cell } \\
\text { International }\end{array}$ & $\begin{array}{l}\text { Stem cell research and } \\
\text { production }\end{array}$ & Human embryonic cell lines & 2000 \\
\hline Cygenics & $\begin{array}{l}\text { Stem cell banking, } \\
\text { devices \& therapeutics }\end{array}$ & $\begin{array}{l}\text { Sample collection and } \\
\text { counselling services }\end{array}$ & 2001 \\
\hline Receptor-Science & Bioinformatics software & $\begin{array}{l}\text { ReceptoMiner }{ }^{\mathrm{TM}} \text { database and } \\
\text { tools }\end{array}$ & 2000 \\
\hline KOOPrime & $\begin{array}{l}\text { IT solutions for life } \\
\text { sciences }\end{array}$ & Platforms, engines, databases & 2000 \\
\hline HeliXense & Bioinformatics platform & $\begin{array}{l}\text { Genomics Research Network } \\
\text { Architecture }\end{array}$ & 2000 \\
\hline Mycosphere & $\begin{array}{l}\text { Fungal diversity, } \\
\text { bioprospecting }\end{array}$ & Contract research & 1997 \\
\hline AP Metrix & $\begin{array}{l}\text { Healthcare and } \\
\text { patient monitoring }\end{array}$ & $\begin{array}{l}\text { RemoteG@re }{ }^{\mathrm{TM}} \\
\text { (patient-provider management } \\
\text { platform) }\end{array}$ & 2000 \\
\hline BioSurfactants & $\begin{array}{l}\text { Surfactants } \\
\text { manufacturing \& } \\
\text { development }\end{array}$ & $\mathrm{N} / \mathrm{A}$ & 2001 \\
\hline
\end{tabular}

*The list of DBFs was compiled from the industry directory and interviews with companies and industry experts. 
regional clinical trials centre. The country is exploiting several advantages including a good healthcare system, a multi-racial population for studying drug effects, and an ideal location for drug trials on Asian diseases. They have had some early success attracting companies like Pharmacia, Novo Nordisk and some of the large contract research organizations (CROs) to establish clinical trial centers in Singapore. Johns Hopkins University and the National University Hospital (Singapore) set up an International Medical Center to provide patient care and to conduct clinical trials in oncology. This centre also offers clinical education programmes and degrees in conjunction with the National University of Singapore. Despite these early successes, there are still relatively few clinical trials taking place in Singapore. This may be due to the strong and growing competition for the Asian clinical research market from Taiwan, Australia and Japan, which have the advantage of larger domestic markets and the fact that pharmaceutical companies may be reluctant to use these clinical trial centres due to an unproven track record.

While the above progress suggests some degree of success in replicating the strategy of leveraging MNCs in the biotechnology sector, a closer examination of the $\mathrm{S}^{*}$ Bio case reveals potential limitations of this strategy. The firm has quickly grown to over 40 people, but having generous EDB funding to fuel its development and access to a proven technology are not substitutes for a true business plan. S*Bio was not created with any distinctive IP, and without IP, it is nearly impossible to build competitive advantage in biotechnology. S*Bio is also competing in a very global industry and having the most comprehensive drug development platform in Singapore does not in itself translate into any clear competitive advantage. In addition, $\mathrm{S}^{*}$ Bio has struggled to recruit the experienced managerial talent needed to provide strategic direction, with a lack of local candidates and difficulty attracting top people from abroad. Thus far, it has not been able to compensate for the lack of internal talent by forming partnerships with other Singapore companies or research institutes. S*Bio's early struggles, along with the difficulty EDB has had in convincing other DBFs to locate in Singapore, suggest the strategy of relying on MNCs to catalyze the growth of a research-driven biomedical HSE may prove difficult to execute. SurroMed, a US-based firm specializing in molecular bar-coding technology, for instance, had opened a US $\$ 25$ million R\&D centre in 2001 with direct investment from EDB. A lot of publicity accompanied this investment, but two years later, Surromed's Singapore subsidiary has been disbanded, and the scientists were incorporated into the Institute of Bioengineering while the technology was returned to the parent company.

\section{An Alternative Model for Biotechnology Development?}

Often lost in the media publicity surrounding the government's major biotechnology initiative is a small set of start-up companies that represent a potential alternative path to the development of a Singapore biomedical cluster. These start-up firms bear a much closer resemblance to early stage counterparts in the US or UK than they do to the better resourced, government-backed ventures like $\mathrm{S}^{*}$ Bio and Merlion. They have typically been based on IP from a university or the inspiration of an entrepreneur and are trying to fill the void between the basic research of the HE sector, and the more mature commercial technologies that VGs, EDB, or foreign pharmaceutical firms are willing to fund. With limited access to these funding sources, they have struggled to grow and had to develop business models that generate revenue quickly. These firms have chosen to locate in Singapore not because of generous investment incentives from the government, but rather because of where the founders were based and the more general business advantages of Singapore - location, strong infrastructure, and good quality of life for professionals.

One set of DBFs that fit this start-up model are companies like HeliXense and Kooprime 
in the emerging field of bioinformatics. A key element in their development has been the availability in Singapore of a strong pool of computer programming skills. As one entrepreneur explained, however, this is primarily not locally grown talent, but rather skilled individuals who have emigrated to Singapore:

Being in Singapore has helped us with getting access to the best people. Singapore is a developed country surrounded by developing countries. It may not be attractive for people from US or Europe, but for Indians and Chinese immigrants it is a good place to live.

Below we describe two other types of companies that fit the start-up model, drawing lessons from their experiences for the capacity and constraints Singapore faces in building a biomedical cluster.

\subsection{Cygenics}

Cygenics is one of several stem cell companies formed in Singapore since 2000. It was created by Steven Fang, a serial entrepreneur who founded several successful businesses while working for the multinational medical device firms, Baxter and Becton Dickenson. Fang got the idea for the company (which was originally launched as CordLife to specialize in banking the umbilical cord blood stem cells of newborns for possible use in later treatments) when one of his friends in the US had a two-year old child with leukemia who was saved with a cord-blood transplant. Recalled Fang: "There was nothing in this area in Asia. But I didn't think the timing was right. There was no awareness yet of cord banking or its applications. So I sat on the idea for four years. Then things got very interesting with the stem cell controversy and publicity in the US."

Fang moved back to Singapore and began market research for CordLife in 2000, raising his first round of $\mathbf{S} \$ 2.5$ million in venture finance in February, 2002. Unlike some of its higher-profile stem cell competitors - ViaCell and ESCell International - CordLife has focused on a combination of cord-blood banking and research into uses of adult stem cells (like those in cord blood) for regenerative therapies. Said Fang:

The science (of embryonic stem cells) is intriguing, but I'm a businessman. I wanted something that would generate revenue quickly. What I'm doing was seen as high risk, but I've shown it isn't. We've had revenue from first month of operation. ... Most biotechnology start-ups come from a research lab with a discovery of the founder. They begin with a bunch of $\mathrm{PhDs}$, have a technical focus and try to raise $\$ 30$ million for five years of research. That's not me. We wanted to be commercially viable from the start. We had sales right away, before we even had equipment, then focused on building the science. That's not the norm. We wanted to validate the market to our investors first, get revenue, and then build to a critical mass.

CordLife received an initial $\$ 500,000$ research grant from the government, but this was much less than the $\$ 7$ million the government provided earlier to US-based ViaCell to set up operations in Singapore. Noted Fang:

The government is interested in stem cells and sees it as a high priority. But it has been investing mostly abroad. I understand the attitude. EDB has built a series of successful industries in the port, chemicals, and electronics. It's appealing for them to sign big deals with MNCs. It's great for the economy and their learning curve. 


\section{David Finegold, Poh-Kam Wong and Tsui-Chern Cheah}

We're locals, we don't have big names ... It may be better for us in long term not to have (large state support) since it forces us to find ways to stand on our own.

This independent approach appears to be paying off for CordLife. It has now expanded into eight countries, including a major focus on China, where there is a high demand for the cord-blood banking service because of the one-child policy and accompanying parental concerns to do everything possible to protect their sole offspring. Fang also has ambitious plans for growing globally through mergers and acquisitions. In April 2003, CordLife completed an $\$ 11$ million merger with Cytomatrix, a Boston, MA-based biotechnology firm that has a patented technology for cell growth that will enable the firm to expand the limited quantity of stem cells in cord blood. The firm then set up another company, Cell Sciences, to market a range of biotechnology devices for cell growth.

With the completion of the mergers, the company was reincorporated in February, 2004 as Cygenics, a holding firm that includes the three businesses. Cygenics now has 41 employees and projects revenue of over $\mathrm{S} \$ 6$ million in 2004. This impressive growth story and rapid path to profitability enabled the firm to list on the Australian Stock Exchange, an AUS $\$ 18$ million initial public offering that occured in May, 2004. Rather than capital, it is skilled manpower that is now the firm's biggest constraint on growth. People are always the biggest challenge, according to Fang, who became CEO of Cygenics, particularly in Singapore and Asia. "It's hard to get good technical people and even harder to get people with bioscience business experience. ... We've had to go outside the industry and train them ourselves or look outside Singapore, hiring ex-pats from the US, Australia, UK, and Scandanavia."

With Cygenics' success appears to have come greater interest from EDB and the government in promoting the firm and other Singapore start-ups. Said Yeo in 2003: "We will strongly support the efforts of promising local biotechnology companies like CordLife (now Cygenics) to strengthen their capabilities and become globally competitive players."

\subsection{Incubators}

In addition to these individual DBFs, several small biotechnology accelerators have emerged in recent years in Singapore, to assist in the creation of new biomedical enterprises. Biotechnology Research Ventures (BRV) is trying to replicate a model that proved successful in the UK for Cancer Research Ventures (CRV), an organization set up to commercialize the outcomes of cancer research funded by the government and the Wellcome Foundation. CRV has created 15 companies in which it retains an equity interest and is now profitable, based on the royalty income they produce. It has since expanded to Europe and was exploring setting up in Australia when Dr. Guy Heathers, BRV's Managing Director, stopped in Singapore and was seduced by the excitement surrounding biotechnology. BRV was created as a joint venture with three primary stakeholders: CRV, the National Cancer Center (NCC), and Singapore Technologies, a government-linked corporation (GLC) indirectly controlled by Temasek Holdings, a government holding company that controls many large domestic firms in Singapore.

Through the funding it provides to NCG through the research councils and Ministry of Health, the government has a significant, albeit indirect, interest in the two firms that BRV has so far spun out, but so far it has played no direct role in the start-ups. Said Heathers:

The traditional Singapore industrial model doesn't work very well in the new knowledge-based economy. It comes from a top-down, logistical mindset. The policymakers in charge are used to dealing with large manufacturing-based companies ... What is not a good fit are very early-stage start-ups from universities. These 
types of companies are quite difficult to deal with; everyone finds them hard to create, but in Singapore, at the moment, it's even harder. Investors aren't happy funding a number of very small companies compared to making a few big investments. Singapore investors don't like the high failure rate.

In trying to introduce a US-UK-style model of university-based spinouts, BRV has encountered several obstacles. The first is that of interesting the researchers in commercializing their discoveries. Observed Heathers: "Researchers are pretty well off when they come to Singapore. They get a good salary, housing, research subsidies, core funding for ten years, and warm weather. They have a very attractive life, then someone comes along and says, "Why don't you give all this up and work hard at creating a company?' They say, 'Why bother?'” The difficulty of attracting scientists to start firms is compounded by the lack of a clear policy on whether researchers can return to their job should the firm fail and the research institutes' reluctance to give the key individuals a significant ownership position:

Their concern is that if founding scientists have equity, then others in NCC may get upset, rather than seeing them as role models... The culture is very competitive here; in the US it is more collaborative; there, if you get to be a millionaire, then I want to learn how I can do it too. It can be hard to build effective teams here if competition rather than collaboration is the culture; biotechnology is a very collaborative business.

With difficulties attracting scientists from university and a shortage of experienced biotechnology management talent in Singapore, BRV has decided to incubate its ventures to a more mature stage than they would in the UK to increase their chance of survival.

BioEnterprise Asia (BEA) was founded by Dr. Gurinder Shahi to help fill a similar need, providing an array of services and management support to help translate early-stage bioscience technologies into viable commercial enterprises. Dr. Shahi, a fourth generation Singaporean, has worked for leading international organizations like the Rockefeller Foundation and the United Nations Development Program and helped establish the International Vaccine Institute (now based in Seoul, Korea). He explained his rationale for setting up BEA in Singapore in addition to wanting to be close to home:

I was convinced that Asia was going to be the growth area for biobusiness in the Twenty First Century. Singapore is a good place to service this region, because its location, cosmopolitan culture, legal framework, and respect for intellectual property make it an efficient place to work. It is for this reason that many multinationals set up their Asian headquarters in Singapore or Hong Kong.

BEA's initial client was Lynk Biotechnologies, the first biotech company to be spun out from the National University of Singapore in February, 2000. Lynk was based around proteomics and other drug discovery technologies developed by Prof. Lee Chee Wee and received early government support from the National Science and Technology Board, the pre-cursor to A*STAR. Recognizing, in the wake of the dot.com bust in 2001, that the Singapore VC community would not support the lengthy and high-risk drug-discovery business model, Lynk sought a way generate early revenue to keep its operations going. Lynk took on several contract research projects and worked to develop newer and more efficacious natural product-based biotech products that could be brought quickly to market. Using knowledge gained from work with clients and in-house research, it developed a range of products that have since been successfully commercialized. These have included a popular hair growth product, Biolyn, that the company developed for a client, and a proprietary technology for delivering drugs through the skin that has led to the release of a range of 


\section{David Finegold, Poh-Kam Wong and Tsui-Chern Cheah}

products including one that uses a natural substance, glucosamine, to treat arthritis. The product has proved so popular that a large OEM approached Lynk about setting up an exclusive partnership to sell Lynk's product in five Asian countries, a contract that far exceeded Lynk's limited production capacity. Building on well-validated demand for its products, the contract from this large customer, and the potential of this technology, Lynk convinced a VG to finance a spin-off subsidiary, MediLynk, which will focus on increasing capacity while working to develop a range of novel products based on the platform. Like Cygenics, Lynk is using the revenue from these products to finance its own research program. Shahi, who has recently completed a book on BioBusiness in Asia, observed:

The experience of companies like Cygenics and Lynk is characteristic of successful life science technology start-ups in Asia. Unlike the US and Europe where a strong tradition of venture-based financing has developed for life science investment, start-ups in Asia find little support or interest from VCs until they are far more advanced and have something to bring to market. Asia-based start-ups have responded to this reality by evolving a revenue-focused business model - where the provision of services or the early sale and distribution of products runs in parallel with their R\&D programs.

As BEA continues to provide acceleration services for start-up opportunities in Singapore and the rest of the region it finds itself increasingly involved in facilitating strategic alliances and partnerships between leading US and European firms and Asian partners.

\section{Conclusions}

Singapore has leveraged the advantages of its central-Asian location, supportive infrastructure for MNCs, a highly literate population, a strong healthcare system, and a diverse population for clinical trials, to make significant strides in developing key foundation elements for a biomedical HSE. To these resources the Government has added crucial, specialized elements needed to support the growth of a cluster in this industry:

- A growing investment in basic research led by, or in collaboration with, leading bioscientists from around the world to serve as the catalyst for biomedical innovation;

- Incentives for FDI that have helped attract a critical mass of pharmaceutical and biotechnology MNCs to Singapore, including some that are now establishing R\&D collaborations with government-funded DBFs, local universities and research institutes;

- A clear regulatory framework that supports the commercialization of biotechnology, including stem cells;

- The newly constructed BioPolis, with state-of-the-art research facilities;

- A growing pool of specialist manpower, including a pipeline of scientists currently undergoing training both locally and overseas and a few bioentrepreneurs who have emigrated or repatriated to Singapore.

Singapore, however, also faces some significant challenges before its biomedical HSE can become self-sustaining. We conclude with a set of general lessons drawn from the case for any country seeking to build a science-based HSE and some potential policy options for Singapore to consider in increasing its chances for success.

\subsection{Need for a Long-Term Commitment}

The very lengthy, highly uncertain, and capital-intensive nature of the biotechnology research and development process means that any country seeking to create a fully-integrated biotech- 
nology HSE (rather than specialize in a latter part of the value-chain, like manufacturing or clinical research) requires a large and sustained financial commitment. This is evident from Germany's BioRegio experiment starting in the latter half of the 1990s where, through a set of changes in the regulatory environment, $\mathrm{R} \& \mathrm{D}$ priorities and the provision of very low-cost capital, the government succeeded in creating, relatively quickly, hundreds of early-stage DBFs only to see many of them fail because they lacked the necessary capabilities and could not raise sufficient subsequent capital to sustain operations (Casper, 2000, 2003; Kaiser, 2003). Singapore's government has been one of the most far-sighted in the world in terms of economic development strategy, and the scale and long-term nature of the government's financial commitment to the biomedical-hub initiative puts Singapore in a favourable position relative to other countries in the region.

\subsection{Avoiding the Vicious Circle}

Singapore's experience suggests that a vicious circle may inhibit the development of a critical mass of firms needed to sustain an HSE. Scientists in universities and research institutes have little incentive to partner with industry, let alone put their careers at risk by entering industry. These scientists have employment security and generous research funding if they remain in the non-profit sector, and are more comfortable publishing their research than commercializing it. The lack of experienced managers and entrepreneurs in the country to aid scientists in building new companies further reduces the incentive to take the risk of moving to a start-up; founders are forced to do it themselves, a task for which many are unprepared. The lack of proven technology, leadership talent, and a critical mass of new companies combines to make it difficult for even those firms that are created to attract the necessary investment. Currently, venture capitalists and the government are focused more globally and on later-stage, less risky investments, leaving the new start-ups with limited alternative sources of funding. This funding gap at the seed stage is particularly serious for life-science start-ups, as few local angel investors have the specialist knowledge to invest in this sector; yet, until there are a sufficient number of DBFs, it is hard for them to justify the time and effort to acquire this expertise. This vicious circle of disincentives to start a new DBF is compounded by the fact that in Singapore, like many Asian and continental European societies, there is a strong stigma associated with being part of a business failure, thus increasing the career risk for individuals who opt for this inherently risky option.

\subsection{Scientific Talent is Key, but Experienced Professionals are also Important}

It is clearly impossible to create a biomedical HSE without having a critical mass of good scientists to generate the IP on which DBFs are built. But the Singapore case shows that the talent-needs for an HSE go far beyond the laboratory: experienced managers to develop products, manage clinical trials, and run companies; knowledgeable life-science investors who understand the unique requirements of this sector; and life-science IP specialists who know the intricacies of structuring licensing arrangements are all needed to build a successful cluster of biotechnology firms.

\subsection{The Global Aspects of Bioentrepreneurship}

While the linkages among the actors in Singapore's biomedical industry are clearly vital to the success of this emerging HSE, this case suggests that entrepreneurship in the biosciences is not the inherently local phenomenon that Feldman and Francis (2003) claim based on their analysis of the US. Most of the DBFs we identified in Singapore were founded and/or staffed 


\section{David Finegold, Poh-Kam Wong and Tsui-Chern Cheah}

by entrepreneurs and scientists who had moved to Singapore. In addition, like other biotechnology clusters, Singapore has created new DBFs, thanks to the investment by large foreign biotechnology and pharmaceutical companies: however, in this case, central government financial incentives appear to have played a greater role than gaining access to the cutting-edge research of DBFs and academic institutions, which appears to be the prime motivation in the two Cambridges, UK and US (Casper, 2003) or San Diego, CA (Cooke, 2002). The role of large pharmaceutical firms may be particularly vital for the long-term success of DBFs in smaller countries, such as Singapore and Israel (Kaufmann et al., 2003), since they provide access to a set of complimentary resources - clinical development, regulatory, sales and marketing expertise - not available domestically, as well as potential finance through strategic partnerships or acquisition (Rothaermel, 2001). The Singapore Government has recognized the ongoing globalization of the bioscience industry, and sought to strengthen its presence through strategic investments in China and India, while having its holding company, Temasek, purchase $25 \%$ of Quintiles, one of the world's leading CROs.

\subsection{Limited Linkages between Biotechnology REDD and Manufacturing}

Even if countries are able to produce some of the talent needed to kick-start the HSE by, as in Singapore's case, recruiting star scientists and educating top young graduates abroad, it is far from apparent that the DBFs they create will become the engines of high-skill job creation on which many policymakers seem to be pinning their hopes. Most of the employment in biotechnology resides in manufacturing, clinical development, and sales, all functions that are increasingly being separated from the organizations performing the R\&D. As Singapore has demonstrated, it is possible to be very successful in attracting jobs in one part of this value chain - manufacturing - without strengths in all of the others.

\subsection{Focus on Existing Competitive Advantages}

Countries currently seeking to build biomedical HSEs must recognize that they are entering an already well-established, very global business. While rapid rates of ongoing biotechnology innovation mean that there are many new opportunities being created in this sector, taking advantage of these opportunities, particularly for a nation that does not already have world-class scientific research institutions, entails carefully identifying those areas where the country has a competitive advantage. For Singapore, this has meant ignoring large segments of the industry that are a poor fit - i.e. bio-agriculture - and concentrating resources on those still emerging niches - stem cells, bioinformatics, clinical trials - where it may be able to compete globally. The case also suggests that efforts to create new companies as a means of transferring leading new technologies to a country are unlikely to succeed if those firms lack some distinctive competitive advantage.

\subsection{Creating a More Collaborative Milieu}

As argued by Cooke (2003) and others, a collaborative milieu is important for dedicated DBFs to thrive. To encourage the development of a more collaborative milieu connecting universities, public research institutes, and DBFs, more than just policies and regulatory changes are needed. A crucial element is the development of trust, embedded in social networks that facilitate knowledge-interaction in the exploratory stage of development, while mitigating against predatory behaviour. Given the limited funding available to a small nation-state such as Singapore to compete in the costly global biomedical industry, researchers in different universities, institutes and firms should be given incentives to collaborate and share resources. 


\subsection{Policy Shift for Singapore: From Leveraging Global MNCs to Promoting Entrepreneurship}

Finally, the Singapore case suggests the need to have a balanced public-policy mix that integrates not only policies for attracting and leveraging global MNCs and building the scientific manpower base, but also policies for promoting independent DBFs and building biomedical business capabilities. In the past, the Singapore Government has emphasized the former, but our analysis and experience of other countries that have successfully developed biotechnology HSEs (Cooke, 2003) suggests that more attention may need to be paid to fostering the development of local biotechnology start-ups by:

- Providing seed funding, similar to the SBIR or STTR grants in the US, that can help early stage start-ups that emerge from the universities or research institutes to reach the stage of development where they can attract venture funding. Steps have recently been taken in this direction with the launch of the Innovate 'N' Create (INC) Scheme and the BioVenture Centre to provide seed-funding and support for Singapore's local start-up companies. The National University of Singapore has also established a seed fund to help its early-stage spin-offs develop to the stage where they can attract venture capital.

- Rethinking the centralization of IP control under Exploit Technologies that may be slowing the commercialization of biomedical innovations;

- Developing the specialized biomedical business skills to complement the emerging cadre of scientists trained on the latest technologies;

- Creating incentives that reward, rather than deter, researchers who collaborate with others and who are willing to pursue careers that entail moves between academia and industry;

- Promoting a culture of entrepreneurship among its young talent, including imparting self-reliance, providing training in basic entrepreneurial skills, and inculcating a greater tolerance for failure. Encouraging steps have been taken in this direction with the creation of a new post of Minister in charge of Entrepreneurship in early 2003.

\section{Acknowlegement}

The authors would like to thank the Freeman Foundation for its financial support and all the individuals who participated in the project.

\section{Notes}

1 These include Gilead, Affymetrix, and Lynx. Interview. Dr. Beh Swan Gin.

2 Date established in Singapore

3 Sources are from company websites or the US Securities and Exchange Commission unless otherwise indicated.

4 http://www.schering-plough.com.sg/spsingapore.htm. Accessed Jun 1, 2003.

5 http://www.asiabiotechnology.com.sg/kh-biotechnology/readmore/vol6/v6n08/wyeth.html. Accessed Jun 1, 2003

6 Establishment date of Sales and Marketing arm

7 Approximately 150 employees in manufacturing while the remaining are employed in sales, marketing and administration. http://www.biomed-singapore.com/bms/browse_print.jsp?artid =79. Accessed Jun 1, 2003.

8 On April 16, 2003 Pharmacia was acquired by Pfizer.

9 http://www.noonanrusso.com/news/surromed/01 news/surro09.24.html. Accessed June 7, 2003

\section{References}

Alder, P. and Kwon, S-W. (2002) Social Capital: Prospects for a New Concept, Academy of Management Review, 27 (1), pp. 17-40. 


\section{David Finegold, Poh-Kam Wong and Tsui-Chern Cheah}

ARnold, W. (2003) Singapore Goes for Biotechnology, New York Times, August 26, W1.

ARrow, K.J. (1962) Economic welfare and the allocation of resources for invention, in, R. NELSON, (Ed.), The Rate and Direction of Inventive Activity. pp. 609 626. Princeton: Princeton University Press.

ARthur, B.W. (1989) Competing technologies, increasing returns, and lock-in by historical events. Economic Joumal, 99, pp. 116-31.

Baum, J. (1996) Organizational Ecology, in S.R. ClegG, C. Hardy and W.R. Nord, (Eds.), Handbook of Organization Studies. pp. 77-114. London, Thousand Oaks: Sage Publications.

Becker, W.E., and William, J.B. (Eds) (1996) Assessing Educational Practices: The Contribution of Economics. Cambridge, MA and London: MIT Press.

BIOMED-SINGAPORE (2003) (http://www.biomed-singapore.com/bms/gi_mc.jsp).

Brandenburger, A. M. and Barry, J. N. (1996) Co-opetition. New York: Currency Doubleday.

Camagni, R. (1991) Local 'milieu', uncertainty and innovation networks: Toward a new dynamic theory of economic space, in R. Camagni, (Ed.), Innovation Networks: Spatial Perspectives. pp. 121-144. London: Belhaven.

Casper, S. (2000) Institutional Adaptiveness, Technology Policy, and the Diffusion of New Business Models: The Case of German Biotechnology, Organization Studies 21, pp. 887-914.

Casper, S. (2003) Commercializing Science in Europe: The Cambridge Biotechnology Cluster, European Planning Studies, 11, pp. 825-823.

Chang, A.L. (2001) Maintaining S'pore's lead in stem-cell race. The Straits Times. Sept 5.

Cohen, S.S., and GARY, F. (1999) Social Capital and Capital Gains in Silicon Valley, Califormia Management Review, 41 (2), pp. 108-130.

Cooke, P. (2003) The evolution of biotechnology in three continents: Schumpeterian or Penrosian?, European Planning Studies, 11, pp. 757-763 (Special Issue on Biotechnology Clusters and Beyond), Oct. 2003.

Crouch, G., Finegold, D. and Sako, M. (1999) Are Skills the Answer? Oxford: Oxford University Press.

DAFT, R.L., and RoBerT H. L. (1984) Information richness: A new approach to managerial information processing and organization design, in B. STAW and L. Cummings, (Eds.), Research in Organizational Behavior, 6, pp. 191-233. Greenwich.

EDB (1999) Annual Report: Life Sciences. http://www.sedb.com/edbcorp/an_1999_13.jsp

EDB (2003) Joint A*STAR and EDB Biomedical Sciences Sectoral Briefing 2003, EDB web site: http://www.biomed-singapore.com/bms/browse_print.jsp? artid = 333 .

Feldman, M.P., and Francis, J.L. (2003) Fortune Favors the Prepared Region: The Case of Entrepreneurship and the Capitol Region Biotechnology Cluster, European Planning Studies, 11, pp. 765-787.

Finegold, D. (1999) Creating self-sustaining, high-skill ecosystems, Oxford Review of Economic Policy, 15(1), pp. 60-81.

Flanigan, J. (2004) To Ease Fears About Jobs, Put Imagination to Work, Los Angeles Times, 4 Jan., C1.

FloridA, R. (2002) The Rise of the Creative Class. New York, Basic Books.

Fritsch, M. (2001) Co-operation in Regional Innovation Systems, Regional Studies, 35(4), pp. $297-307$.

Hannan, M. T., and Freeman, J. (1977) The Population Ecology of Organizations, American Journal of Sociology, 82(5), pp. 929-964.

IDC (2002) The Merlion Roars Back: Singapore's Biotechnology and Pharmaceutical Ecosystem, Report \#AP281101J.

Kaufman, D., Schwartz, D., Frenkel, A., and Shefer, D. (2003) The role of Location and Regional Networks for Biotechnology Firms in Israel, European Planning Studies, 11, pp. 823-841.

KaIser, R. (2003) Multi-level Science Policy and Regional Innovation: The Case of the Munich Cluster for Pharmaceutical Biotechnology, European Planning Studies, 11, pp. 841-859.

Kong, H.L. (2003) Personal interview with authors, Singapore Biomedical Research Council, January.

Lawton Smith, H., Tracey, P., and Clark, L. G. (2003) European Policy and the Regions: A Review and Analysis of Tensions, European Planning Studies, 11, pp. 859-875.

Markusen, A. (1996) Sticky places in slippery space: A typology of industrial districts, Economic Geography, 72(3), pp. 293-313.

Niosi, J., and BAS, T.G. (2003) Biotechnology Megacentres: Montreal and Toronto Regional Systems of Innovation, European Planning Studies, 11, pp.789-804. 
Piore, M.J., and Charles, F.S. (1984) The Second Industrial Divide: Possibilities for Prosperity. New York: Basic Books.

Porter, M. (1998) Clusters and the new economics of competition, Harvard Business Reviere, 78, pp. 77-90.

ShaHI, G. (2004) BioBusiness in Asia. Singapore: BioEnterprise Asia.

SAywell, T. (2001) Medicine for the Economy, Far Eastern Economic Review, Nov 15.

Stein, S. (2003) Consultant for Singapore start-ups, Personal interview with researchers.

Storper, M. and ScotT, A. (1990) Work organisation and local labour markets in an era of flexible production, International Labour Review, 129(5).

StreEcK, W. (1989) Skills and the Limits of Neo-Liberalism, Work, Employment and Society, 3.1. pp. 89-104.

Swann, P.G.M., Prevezer, M. and Stout, D. (Eds.) The dynamics of industrial clustering. Oxford, New York: Oxford University Press.

Teubal (1997) A Catalytic and Evolutionary Approach to Horizontal Technology Policy, Research Policy, 25(8), pp. 1161-1188.

TRIENDL, R. and Yoon, R. Singapore from microporcessors to microarrays?, Nature Biotechnology, 19, June 2001, pp. 521-22.

VIG, P. (2003) Consultant for Singapore start-ups, personal interview with researchers.

Wolter, K. (2002) Can the US Experience Be Repeated? The Evolution of Biotechnology in Three European Regions (mimeo). Duisburg University: Germany.

WONG, P.K. (2001) Leveraging Multinational Corporations, Fostering Technopreneurship: The Changing Role of S\&T Policy in Singapore, International Joumal of Technology Management, 22, (5/6), pp. 539-567.

Wong, P.K. (2002) Globalization of American, European and Japanese Production Networks and The Growth of Singapore's Electronics Industry, International Journal of Technology Management, 24 (7/8), pp. 843-869.

Young, R. (1988) Is population ecology a useful paradigm for the study of organizations?, American foumal of Sociology, 94(1), pp. 1-24.

Zucker, L., and DARby, M. (1996) Star scientists and institutional transformation: Patterns of invention and innovation in the formation of the biotechnology industry, Proceedings of the National Academy of Sciences, USA, 93, pp. 12709-12716. 
